\title{
Environmental and self-sufficiency assessment of the energy metabolism of tourist hubs on Mediterranean islands: the case of Menorca (Spain)
}

Héctor Romanos ${ }^{1}$, Esther Sanyé-Mengual ${ }^{1,{ }^{*}}$, Catalina Molina ${ }^{1}$, M. Antònia Oliver ${ }^{1}$, , Núria Ruiz ${ }^{1}$, Marta Pérez $^{2}$, David Carreras ${ }^{2}$, , Martí Boada ${ }^{1,3}$, Jordi Garcia-Orellana ${ }^{1,4}$, Jordi Duch ${ }^{3}$, Joan Rieradevall ${ }^{1,5}$

${ }^{1}$ Institut de Ciència i Tecnologia Ambientals (ICTA), Universitat Autònoma de Barcelona (UAB), 08193 Bellaterra (Barcelona), Spain

${ }^{2}$ Observatori Socioambiental de Menorca (OBSAM), Institut Menorquí d’Estudis, 07702 Maó (Spain)

${ }^{3}$ Departament de Geografia, Universitat Autònoma de Barcelona (UAB), 08193, Bellaterra (Barcelona), Spain

${ }^{4}$ Departament de Física, Universitat Autònoma de Barcelona (UAB), 08193 Bellaterra (Barcelona), Spain ${ }^{5}$ Departament d'Enginyeria Química (XRB), Universitat Autònoma de Barcelona (UAB), 08193, Bellaterra (Barcelona), Spain

${ }^{*}$ Corresponding author: Esther.Sanye@uab.cat, Tel. +34.935813760, Fax. +34.935868008

\section{Abstract}

Energy performance of island tourism has been analyzed in the literature. However, tourist services tend to concentrate in tourist hubs, especially where mass tourism predominates (e.g., Mediterranean), and the energy metabolism of these systems has not yet been assessed. The present paper models and estimates the energy metabolism of tourist hubs in the Menorca Island (Spain) by integrating social, geographical and environmental methods. Mobility (both external and internal) and consumption of lodging services were characterized through surveys to users (tourists) and business managers. An environmental assessment evaluated $\mathrm{CO}_{2}$ emissions, and energy self-sufficiency potential was estimated via GIS data. The results indicate that, on average, a tourist consumes $4,756 \mathrm{MJ}$ with associated emissions of $277 \mathrm{~kg}$ of $\mathrm{CO}_{2}$ per stay ( 20 days on average). Of all the energy flows, external mobility contributes the most to total emissions $(77 \%)$. For every day spent in a tourist hub, a tourist consumes between 29 and $93 \mathrm{MJ}$ in lodging services, consumption that could be 100\% satisfied by 
photovoltaic systems, and these systems would result in positive effects for the island. Sustainable tourism management might focus on promoting environmentally friendly transportation, energy efficient practices, and environmental communication through ecolabeling.

Keywords: energy modeling, tourist hubs, self-sufficiency

\section{Introduction}

Tourism, defined as "the activities of persons traveling and being in a place outside their usual environment for not more than one consecutive year for leisure, business and other reasons" (UNWTO), is the fastest growing economic sector in many countries and regions worldwide. It accounts for 5\% of global GDP (UNWTO, 2012) due to the high contribution of tourism to Gross Value Added (GVA). Additionally, tourism is one of the most dynamic sectors of the world economy (Radulescu, 2011) and is responsible for between $6 \%$ and $7 \%$ of total world employment, up to $25 \%$ in areas where tourism is the main source of economic support (UNWTO, 2012).

The Fordian tourism period (1900-50), which was characterized by reduced bourgeois mobility to foreign countries for therapeutic reasons (Riera et al., 2009), shifted to a mass tourism with a boom of users in the 60 s due to improved labor conditions for the working class, which led to a massive increase in tourist mobility (Apostolopoulos \& Gayle, 2002). This shift resulted in the now-predominant type of tourism: mass tourism, which is concentrated in coastal areas (such as the south Mediterranean) and is characterized by reduced interest in local culture and heritage. 
Although the current tourism model results in economic and social development, it is associated with a number of environmental impacts (Apostolopoulos \& Gayle, 2002; Cànoves et al., 2004; UNWTO, 2008) and produces $5 \%$ of the global emissions of $\mathrm{CO}_{2}$ (World Economic Forum, 2009). Gössling (2002) summarizes the global environmental impacts of tourism as follows: changes in land cover and land use, large energy use, effects on biodiversity (biotic exchange and extinction), disease exchange and dispersion, and changes to people's perception and understanding of the environment.

However, tourism has been identified as an economic sector that is dependent on the environment and its resources (e.g., landscape) (Radulescu, 2011). Therefore, the need for a more environmentally friendly tourism model has introduced the concept of ecotourism or sustainable tourism. The first definition of this model is found in the Manila Declaration of world tourism (1980), which states that "the satisfaction of tourism requirements must not be prejudicial to the social and economic interests of the population in tourist areas, to the environment or, above all, to natural resources, which are the fundamental attraction of tourism, and historical and cultural sites". This sustainable model aims to guarantee the quality, continuity and balance between tourism and environmental needs (Radulescu, 2011) while ensuring the future use of natural and cultural resources (Honey \& Krantz, 2007) and satisfying the tourist with a nature-based model (Lu \& Stepchenkova, 2012) that equally distributes the economic and social benefits throughout the population.

Mass tourism destinations (e.g., sun and beach) tend to concentrate the requisite tourism infrastructure and services by the creation of tourist hubs (Montaner Montejano, 1991), which are areas that have recently evolved into "all-inclusive" tourism resorts in developing regions with an emergent economy and large coastal areas to exploit 
(Papatheodorou, 2004). These tourist hubs are associated with the presence of extensive construction, commercial and services areas, which have a significant impact on land use and occupancy. This impact is greater in areas such as the Mediterranean, where tourism is seasonal due to the climate conditions, in contrast to temperate areas with lower seasonality (e.g., the Canary Islands or Cancun). Because tourist hubs are the primary mass tourism destinations, their design are largely responsible for environmental impacts, which therefore tend to be seasonal (Deyà Tortella \& Tirado, 2011). First, tourist hub infrastructure is overused during high season and underused in the off season because the hubs are designed for the population peaks. This has collateral effects related to urbanization, such as biodiversity impacts (e.g., barrier effects, impacts on fragile areas). Secondly, peak water demands may match the minimum rainfall values in some areas, such the Mediterranean, causing hydric stress in the summer (Agell et al., 2011; OSE, 2011; Weaver \& Opperman, 2000).

Energy consumption is also related to the high demand that must be supplied through an oversized infrastructure. Energy has been identified as one of the most significant impact factors of tourism, due not only to the energy consumption during the stay but also to transportation to the destination, particularly on islands. In $2004,39 \%$ of anthropogenic greenhouse gas (GHG) emissions were due to energy consumption (IPCC, 2007), of which transportation contributes 23\% (Kahn Ribeiro et al., 2007). Additionally, households and commercial buildings represented $8 \%$ of overall emissions (IPCC, 2007). Quantification of tourist hub energy metabolism is necessary to show the contribution of each flow and identify potential energy reduction strategies. The energy metabolism refers to the characterization of the energy flows of a system from an industrial ecology perspective (Ayres \& Ayres, 2002). 
Although initial research on the environmental impacts of tourism focused mainly on the negative impacts to the local flora and fauna (e.g., Weaver \& Lawton, 2007), understanding energy metabolism and other resources flows has received attention over the last decades. For example, Deyà Tortella \& Tirado (2011) quantified the hotel water consumption of Mallorca Island and Hadjikakou et al. (2013) estimated to total water use (both direct and indirect) of tourism in the Mediterranean. Specifically, energy and transportation have been key issues in several studies due to their importance regarding sustainability. Examples include the accounting of the total $\mathrm{CO}_{2}$ emissions associated with tourist transport to Antarctica (Farreny et al., 2011) and the analysis of road transport in the island of Lanzarote (Spain) (Martín-Cejas \& Ramírez, 2010). Furthermore, Beccoli et al. (2009) paid attention to the energy consumption of hotels and the energy saving measures considered in this sector. Moreover, industrial ecology tools have been used to assess the environmental performance of tourism, and new methods have been applied, such as life cycle assessment (e.g., Chambers, 2004; De Camillis et al., 2008; König et al., 2007; Kuo and Chen, 2009; Kuo et al., 2012; Sissman, 1994) or the ecological footprint indicator (e.g., Gössling et al., 2002; Hunter and Shaw, 2007; Martín-Cejas \& Ramírez, 2010).

Tourism studies have also been carried out at different scales. Geographical boundaries are generally used, such as for country analysis (e.g., Perch-Nielsen et al., 2010). Moreover, islands have been the center of some studies due to the importance of air travel in the energy balance (Gössling et al., 2002; Kuo et al., 2012; UNWTO, 2008). On the other hand, other tourism studies have assessed services, such as a package holiday (Chambers, 2004) or different accommodation services (Petti and Tontodonati, 2002). However, the role of tourist hubs as functional entities that concentrate multiple 
services and facilities with specific energy and environmental flows has not yet been characterized.

The Mediterranean is a tourist zone with a high presence of mass tourism concentrated in tourist hubs, representing $18.5 \%$ of the tourist market, of which Spain is the fourth most popular tourist destination worldwide, with 56.7 million tourists during 2011 (UNWTO, 2012). Spanish tourism is concentrated (26\%) in the Balearic Islands (OSE, 2011), with Menorca Island accounting for 4.1\% (OSE, 2011) of all Spanish tourism. Tourism in Menorca started later than in the other Balearic Islands (late 1970s) because Menorca was considered a political-military geostrategic point and, from the economic point of view, tourism had to compete with an advanced agriculture and a strong industrial base (Fullana, 2005). As a result, the touristic model of Menorca is unique, with a high-quality environment and the specified goal to preserve this environment. In 1993 the island was declared a UNESCO Biosphere Reserve, even though most of the tourist areas that were analyzed had already been built. Menorca has been energy dependent on Mallorca since 1975 because there is only one thermal plant for power generation (OBSAM, 2011).

The Mediterranean may be one of the most responsive regions to global climate change (Giorgi, 2006; Giorgi \& Lionello, 2008). Consequently, the tourism industry may be affected (Valls \& Sardà, 2009), making it a less sustainable activity not only environmentally but also economically (Perry, 2006). Hein et al. (2009) estimated that current Spanish touristic volume could be reduced between 5 and $14 \%$ based on the current estimated temperature increase projections. This may incentivize tourism management to become more active regarding strategies to reduce the current contribution of tourism activities to climate change, specifically regarding those highest contributing flows such as energy and transportation. 
In this context, there is a need to characterize the energy metabolism of tourist hubs where mass tourism is concentrated, to assess environmental performance, analyze the potential for energy self-sufficiency and to identify sustainable strategies for improving tourism management. Moreover, this research focuses on the evaluation of the entire aggregation of infrastructures and services (i.e., tourist hub system) instead of isolated systems (i.e., buildings), according to the trends observed in the Mediterranean. Menorca was selected as a case study due to the specifications of the touristic model and the representation of the Mediterranean islands through the heterogeneity of its tourist hubs.

The main objective of this paper is to analyze the energetic metabolism and the associated emissions of the tourist hubs of Menorca (Balearic Islands). To achieve this goal, the specific aims are as follows: (a) characterize the tourist hubs (b) characterize the tourist profile, (c) quantify the energetic flows associated with mobility, not only external but also internal, (d) determine the energy consumption during the stay, (e) evaluate the photovoltaic production potential for each hub, (f) identify the influence of the type of hub (hotel, mixed, or residential) on the energetic profile, and $(\mathrm{g})$ define the most relevant strategies for a sustainable energy model for the tourist hubs and for the whole island.

\section{Methods}

\subsection{Study system: the tourist hubs}

Menorca Island is one of the Balearic Islands located in the Mediterranean Sea (Figure 1). It has 44 tourist hubs (PTI, 2006), of which 10 were selected as a representative 
sample of the different types of tourist hubs in the island as well as the coastal Mediterranean. The analyzed hubs are Punta Prima, Arenal d'en Castell, Sant Tomàs, Platges de Fornells, Son Parc, Cala en Bosch, Son Bou, Cap d'Artrutx, Cala Morell and Binibèquer Nou (Figure 1). The case study set accounts for $43.6 \%$ of the total accommodation vacancies of the Island (PTI, 2006).

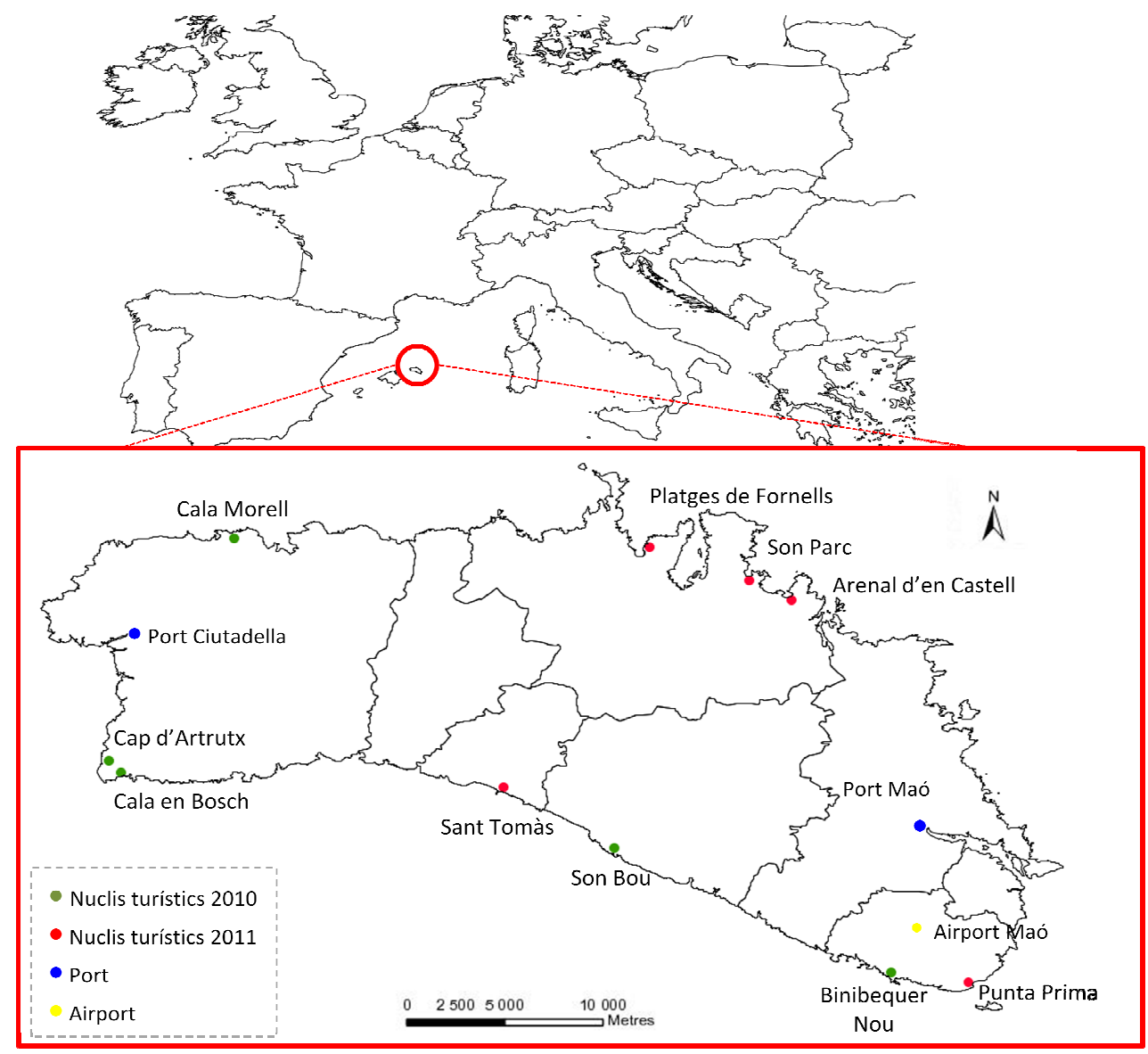

Figure 1. Menorca is located in the West Mediterranean sea. The 10 tourist hubs analysed are distributed among the different municipalities of Menorca, identified by year of data collection.

The tourist hubs selected are representative of different types of hubs in the Mediterranean coast. Demographic and territorial facts highlight the contrasts within the 
sample (Table 1). Tourist hubs are representative of the territory (situated in different municipalities), have different population patterns (from 158 to 530 permanent inhabitants), and are divergent in occupied surface (from almost 2 ha to more than 23 ha of tourist hub area). Finally, mass tourism representativeness is shown by the low values of permanent occupancy (from 3.9 to $20.5 \%$ ), values that note an underuse of hub infrastructure. Moreover, this underutilization is more extreme for hotel hubs (3.9 $17.7 \%)$ than in the residential hubs $(14.9-20.5 \%)$.

Table 1. Tourist hubs characteristics: municipality, population (permanent and peak), permanent occupancy, total surface and surveyed users, by tourist hub.

\begin{tabular}{|c|c|c|c|c|c|c|}
\hline \multirow[b]{2}{*}{ Tourist hub } & \multirow[b]{2}{*}{ Municipality } & \multicolumn{3}{|c|}{ Population } & \multirow{2}{*}{$\begin{array}{c}\text { Total } \\
\text { surface } \\
{\left[\mathrm{m}^{2}\right]}\end{array}$} & \multirow[b]{2}{*}{$\begin{array}{l}\text { Surveyed } \\
\text { users }\end{array}$} \\
\hline & & Permanent & Peak & $\begin{array}{c}\text { Permanent } \\
\text { occupancy (\%) }\end{array}$ & & \\
\hline $\begin{array}{l}\text { Cala en } \\
\text { Bosch }\end{array}$ & Ciutadella & 204 & 5.201 & 3,9 & 364.256 & 117 \\
\hline Son Bou & Alaior & 175 & 1.704 & 10,2 & 172.800 & 57 \\
\hline Punta Prima & Sant Lluís & 485 & 2.730 & 17,7 & 797.400 & 64 \\
\hline $\begin{array}{l}\text { Arenal d'en } \\
\text { Castell }\end{array}$ & Es Mercadal & 426 & 4.297 & 9,9 & 375.100 & 116 \\
\hline Sant Tomàs & $\begin{array}{l}\text { Es Migjorn } \\
\text { Gran }\end{array}$ & 158 & 3.910 & 4,0 & 454.200 & 73 \\
\hline $\begin{array}{l}\text { Platges de } \\
\text { Fornells }\end{array}$ & Es Mercadal & 262 & 4.599 & 5,7 & 484.000 & 84 \\
\hline $\begin{array}{l}\text { Cap } \\
\text { d'Artrutx }\end{array}$ & Ciutadella & 401 & 3.465 & 11,6 & 528.244 & 98 \\
\hline Son Parc & Es Mercadal & 369 & 3.604 & 10,2 & 2.328 .700 & 71 \\
\hline Cala Morell & Ciutadella & 244 & 1.634 & 14,9 & 677.630 & 32 \\
\hline $\begin{array}{l}\text { Binibèquer } \\
\text { Nou }\end{array}$ & Sant Lluís & 530 & 2.582 & 20,5 & 797.886 & 79 \\
\hline
\end{tabular}

\subsection{Energy and environmental metabolism}


The study system includes the entire energy metabolism observed in the coastal tourist hubs of Menorca and is based on a lifecycle approach; therefore, the beginning to the end of the trip is considered. Energy flows can be divided into three main stages (Figure 2): the external mobility of the user associated with the round-trip to the destination, the internal mobility within the island and the power consumption of the tourist facilities used during the stay. Only electricity is considered for power consumption in lodging services because it accounts for the largest fraction of energy consumed in lodging and households in Menorca (OBSAM, 2009) as well as the managers indicated electricity as the unique source of energy in the questionnaires. Finally, we quantified the selfsufficiency potential of the tourist hub via the use of solar photovoltaics. This is considered a complete analysis of the energy consumption and its environmental impact since the system has been expanded to also include transportation as well as an evaluation of touristic infrastructure underuse (i.e., Infrastructures designed to satisfy the peak population in summer).

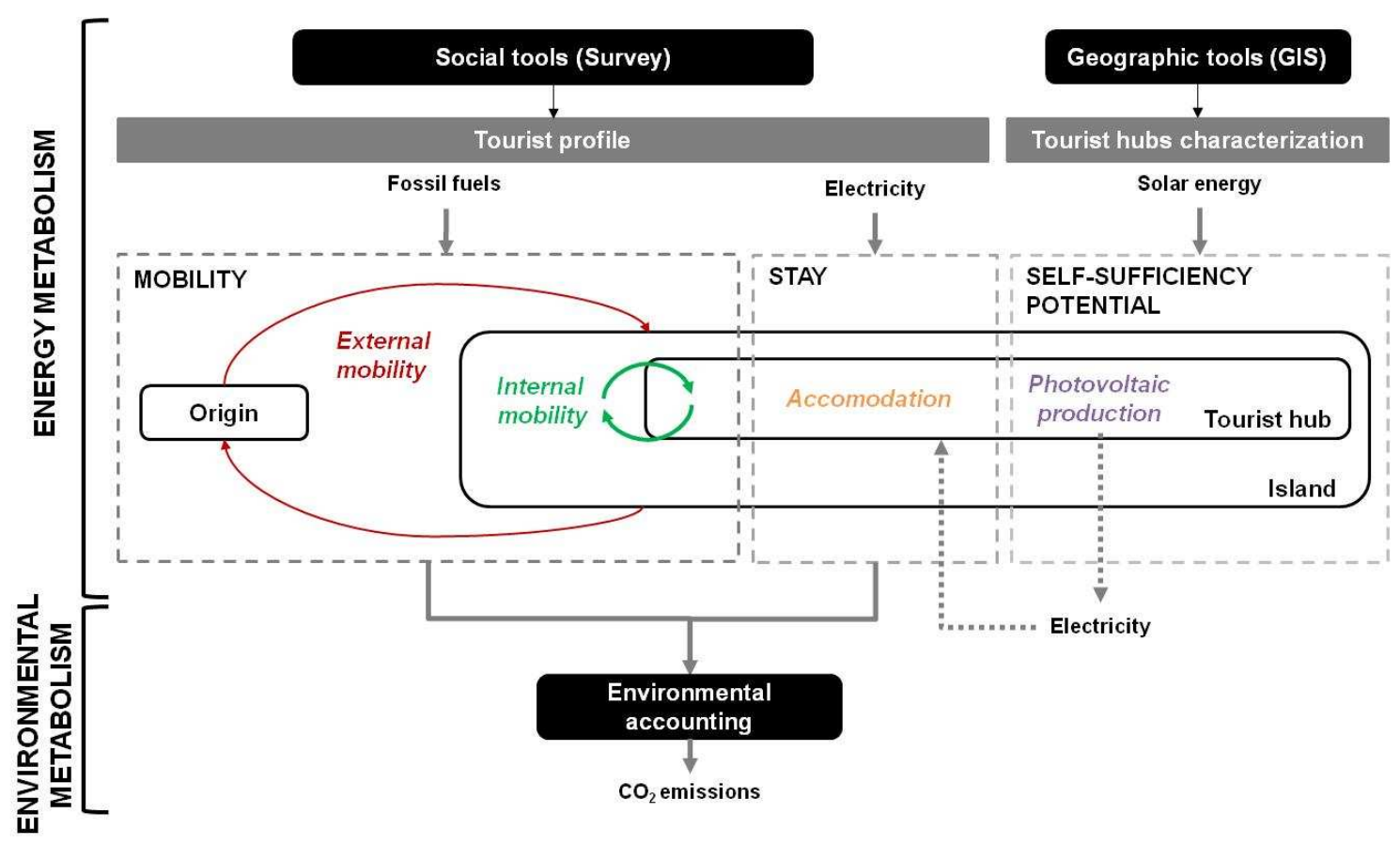


Figure 2. Energy and environmental metabolism of tourist hubs: tools and flows related to mobility and consumption during the stay and sustainable strategies for selfsufficiency of tourist hubs

\subsection{Tools}

The research combined three different tools to evaluate the entire energy and environmental metabolism of tourist hubs. Social and geographic tools were integrated for data gathering with the aim of characterizing energetic metabolism, while environmental accounting methods were used to assess the environmental metabolism. Finally GIS and environmental accounting were combined to assess the self-sufficiency potential (Figure 2).

\subsubsection{Social tools: surveys}

Although the socio-environmental institute OBSAM monitors some tourism aspects such as the tourism distribution by nationality or the total amount of accommodation vacancies that could be used in the assessment, data per tourist hub areas is not available. A survey was therefore conducted on the island of Menorca (July-August 2010 and 2011) to determine tourist profiles and mobility habits during their stay on the island. The model is based on the survey proposed by Agell et al. (2011) and consists of 18 questions divided into four sections: tourist profile (origin, means of transport, and length of stay), type of accommodation, internal mobility (movement patterns) and social information (education and income) (Appendix 1). 
The sample for the survey (n) was quantified according to the formula (1) (Groves et al., 2009), considering the confidence coefficient (for $95 \%, Z=1.96$ ), the positive variance (p) and negative variance ( $q$ ) (both $p=q=0.5$ to estimate the maximum error), the total population ( $\mathrm{N}=220819)$ and the error ( $\mathrm{E}$, acceptable up to $5 \%)$.

$$
\text { (1) } n=\frac{Z^{2} \cdot p \cdot q \cdot N}{N \cdot E^{2}+Z^{2} \cdot p \cdot q}
$$

A total of 754 tourists were surveyed, distributed among the 10 tourist hubs according to the accommodations established in the Insular Territorial Plan (ITP, 2003). The distribution of places among the available types of accommodation and touristic hubs were considered for the stratification of the sample. The objective was to take data from $5 \%$ of the total number of accommodation places (see Table 1).

Given the lack of information on consumption patterns at island lodging services, a manager questionnaire was also distributed (Appendix 2) to determine the daily average consumption per tourist through questions about electricity consumption habits. The questionnaire was conducted in 45 establishments distributed throughout 8 of the 10 hubs studied (2010 and 2011). For Sant Tomàs and Platges de Fornells, average lodging service power consumption was estimated according to the power consumption of their municipalities during peak tourism months (July-August) (OBSAM, 2012) and peak population values in the different tourist hubs.

\subsubsection{Geographic tools: Geographic Information Systems (GIS)}

Geographic Information Systems (GIS) were used to digitalize tourist hub information gathered during field work (July-August 2010 and 2011). This tool was used for tourist hub characterization and self-sufficiency assessment. First, land use was identified, differentiating between tourist accommodations, residential, services, commercial, 
facilities, roads, without use and others. This step was the basis for three tourist hubs categories: hotel, mixed and residential, as well as for identifying major tourist hub characteristics to be analyzed, such as services supply. Second, data for the energy self-sufficiency assessment were gathered because rooftop type is crucial for quantifying the potential production of photovoltaic systems. Building roofs were classified into three groups: inclined, flat or smaller than $80 \mathrm{~m}^{2}$ (the minimum area for a profitable photovoltaic system (IDAE, 2006)) (Figure 3). Finally, other particular elements were also noted, for example swimming pools, non-built private plots or underconstruction areas. ArcView (ESRI, Redlands, California) software was used, and the cartographic base was the orthophotomap of Menorca Island of 2007 (accessible on IDE-Menorca http://cartografia.cime.es/portal.aspx). 


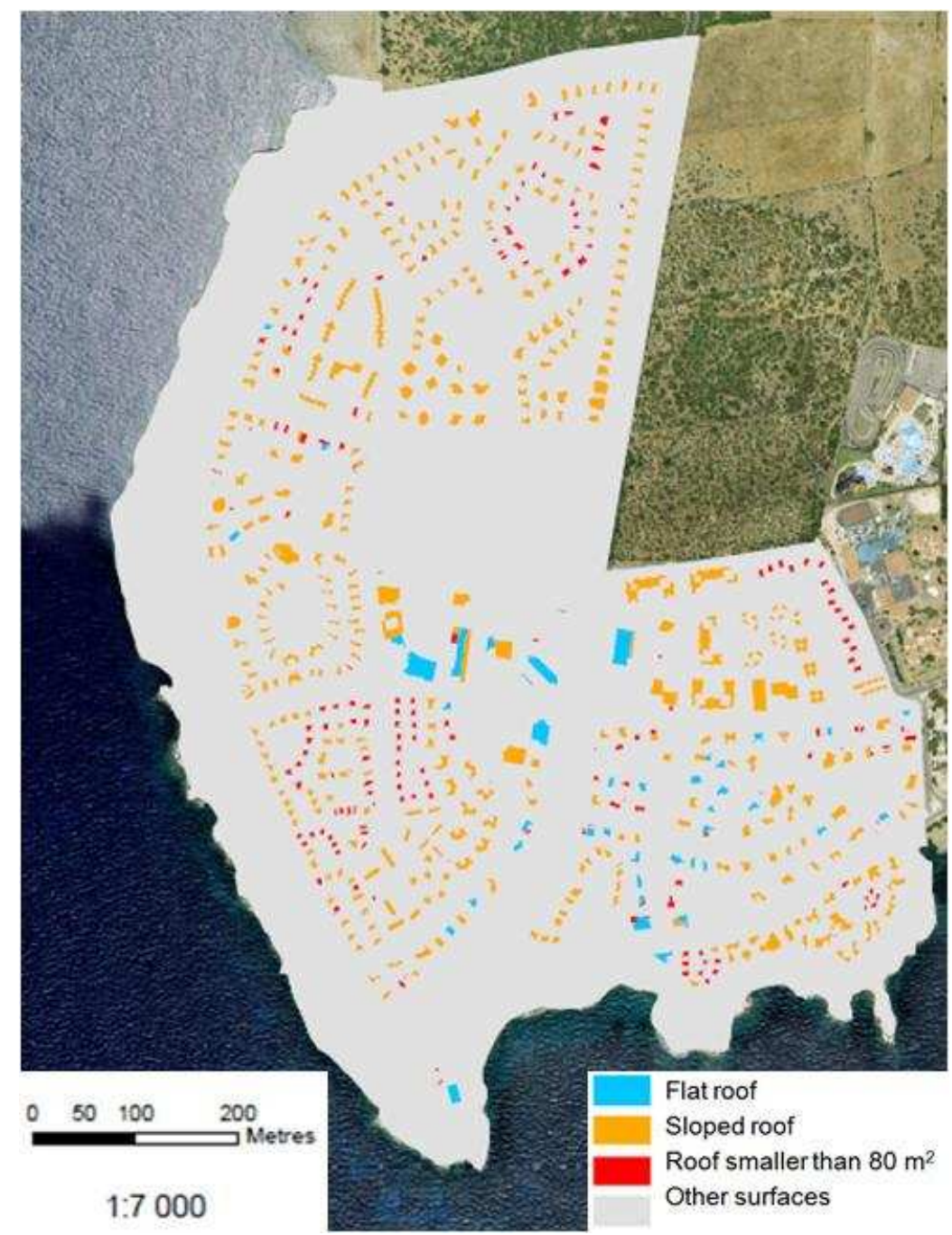

Figure 3. Digitisation of the touristic hub of Cap d'Artrutx: Identification of the type of roof for evaluating the photovoltaic potential.

\subsubsection{GIS and potential production assumptions for the energy self-sufficiency potential}

The energy self-sufficiency potential is based on the potential solar photovoltaic selfsufficiency. This renewable energy system was the only considered in the analysis as:

(a) Renewable energy is expected to be produced in the same building, (b) Rooftops are the focus of the analysis, (c) Data is collected through field work and GIS 
calculations, (d) Solar systems are the most suitable for urban areas (La Gennusa et al., 2011), (e) The availability of geothermal points is still not determined for Menorca, (f) Renewable systems are expected to substitute electricity and to be integrated in the grid system.

Although GIS models for predicting the potential implementation of solar energy systems in urban areas are available in the literature (i.e., La Gennusa et al., 2011), a simple model based on (1) field work data collection, (2) GIS rooftop analysis and (3) potential energy production quantification was designed for the case study.

In this model, the roof classification for each tourist hub determined during the field work and the creation of a GIS database were the basis for accounting the potential for electric self-sufficiency for each system. The assumptions used to calculate the implementation area for photovoltaic systems were as follows: First, only $25 \%$ of roofs were considered suitable for installation of a photovoltaic system considering that (a) roofs of the analyzed systems are homogeneously distributed in all orientations, (b) the minimum size needed to accommodate a photovoltaic system is $80 \mathrm{~m}^{2}$ (IDAE, 2002a), and (c) the roofs suitable for PV installation are those flat roofs with a slope between - 45 and 45 degrees. Second, a yield of 0.73 was considered for PV production systems (Marion et al., 2005).

The average amount of solar energy that can be stored daily for a system (tourist accommodation or hub) is calculated as the energy potential $\left(E_{p}\right)(2)$ based on IDAE (2002b). $E_{p}$ is calculated based on the average daily irradiation value $\left[G_{d m}(\alpha, \beta)\right]$ for a determined period of time (monthly or yearly) on a plane with an azimuth $\alpha$ and inclination $\beta$ in the area of the considered system $\left(\mathrm{kWh} \cdot \mathrm{m}^{-2} \cdot \mathrm{day}^{-1}\right)$. The installed potential $\left[\mathrm{P}_{\mathrm{imp}}\right]$ of the system $(\mathrm{kW})$ considers the energetic yield of the installation or 
performance ratio $[\mathrm{PR}]$ and the irradiance under standard measurement conditions, which is $1 \mathrm{~kW} / \mathrm{m}^{2}\left[\mathrm{G}_{C E M}\right]$. Daily irradiance $\left(G_{d m}(\alpha, \beta)\right)$ was determined from the photovoltaic GIS system CM SAF-PVGIS, available online (IDAE, 2002b), corresponding to the city of Maó (Menorca). The optimum angle considered for calculations was $34^{\circ}$.

$$
\text { (2) } E_{p}=\frac{G_{d m}(\alpha, \beta) x P_{i m p} X P R}{G_{C E M}}
$$

The energy self-sufficiency potential is assessed per year according to the potential electricity production of the identified rooftop potential in GIS and the energy consumption of each tourist hub (obtained from the questionnaires to managers and data from OBSAM). The self-sufficiency potential is expressed in percentage (\%) and values higher than $100 \%$ express surplus of electricity. This surplus of electricity is considered to be sold and injected to the grid, while avoiding storage requirements for later uses. The monthly energy self-sufficiency was also considered in the assessment in order to show the seasonality restrictions for surplus production (i.e., due to increase of population and therefore energy consumption in certain months) as well as to show the quantity of self-sufficient months per type of hub, which are evaluated in the discussion.

\subsubsection{Environmental accounting and indicators: energy flows and $\mathrm{CO}_{2}$ emissions}

The accounting of energy flows and the resulting $\mathrm{CO}_{2}$ emissions were based on two data sources: the survey, which identified the tourist profile (i.e., origin and transport), and the questionnaire for the managers of lodging services (i.e., the quantification of energy consumption). The calculation method, energy consumption and emission factors considered in the analysis vary according to mode of transport (Table 2). The 
selection of the methods was performed according to the specifications of the Catalan government for accounting $\mathrm{CO}_{2}$ emissions (Oficina de Canvi Climatic, 2011). Allocation per person was done according to factors per passenger (e.g., ship), calculators per passenger (i.e., plane), average consumption per tourist (i.e., lodging) and considering the occupancy of the vehicle (i.e., car). The total values per trip were obtained considering the length of the stay per each tourist (according to formula (3)).

Table 2. Method, variables and specific factors used for the energy modelling and the $\mathrm{CO}_{2}$ accounting steps, by energy flow: external mobility, internal mobility and consumption during stay.

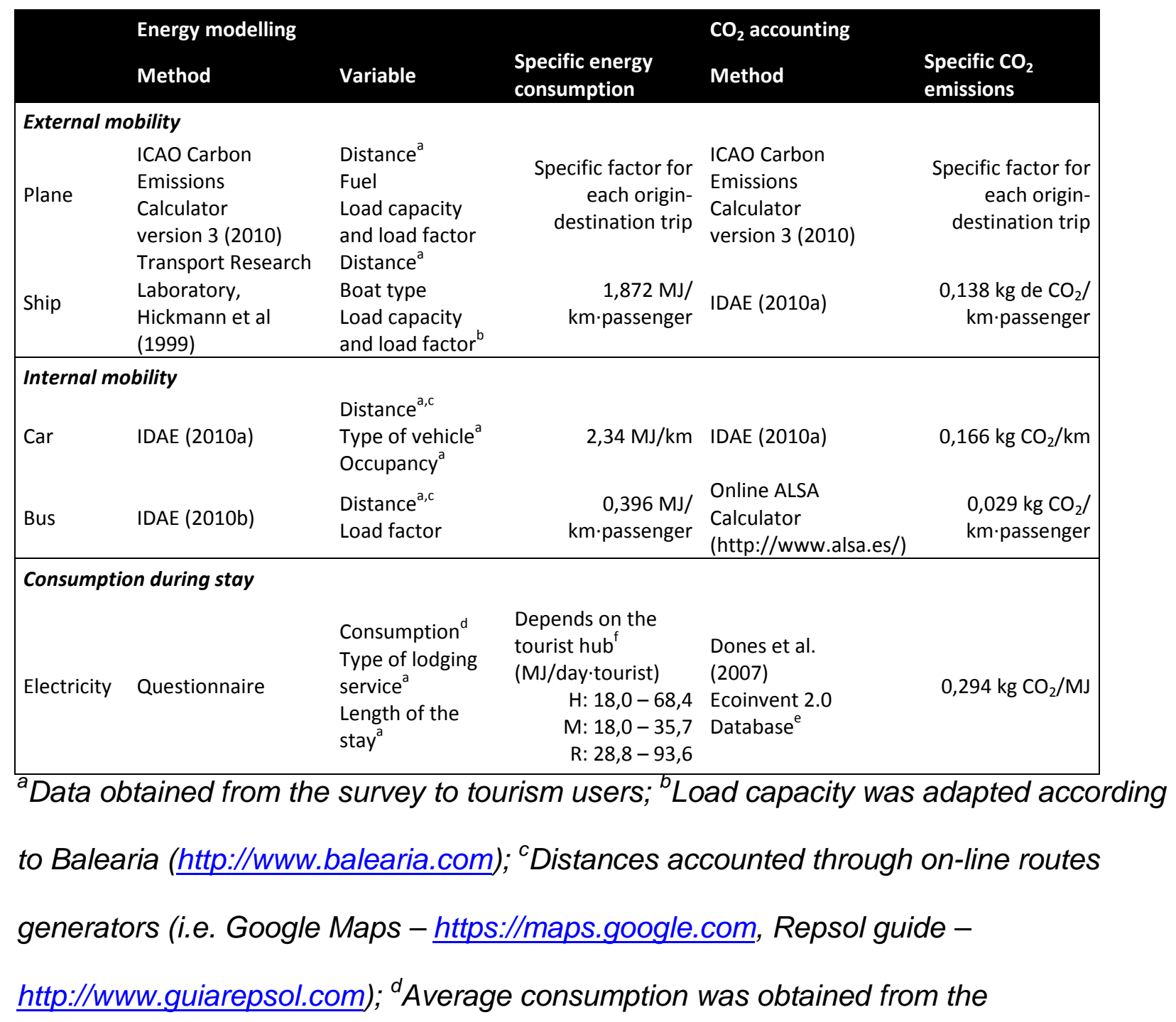


questionnaire to lodging managers; ${ }^{e}$ The electric mix of the island of Menorca in 2010 (OBSAM, 2011) was used for the calculations; ${ }^{f}$ Consumption ranges are presented according to the results by type of hub ( $H$, hotel; $M$, mixed; $R$, residential).

The energy metabolism of the tourist hubs is assessed through four indicators: Energy consumption per stay (EC) (3), Daily energy consumption ( $\left.E C_{d}\right)$ (4), Energy consumption per built area $\left(\mathrm{EC}_{\mathrm{ba}}\right)(5)$ and Energy consumption per overall area $\left(\mathrm{EC}_{\mathrm{oa}}\right)$ (6). Indicators aim to show how the different variables might affect the results: tourist profile, length of stay and tourist hub density. These indicators enabled comparison within tourist hubs and types as well as consideration of the three energy flows: external mobility $\left(M_{\text {ext }}\right)$, internal mobility $\left(M_{\text {int }}\right)$ and consumption during the stay $\left(S_{e c}\right)$.

(3) EC $\left(\frac{M J}{\text { tourist trip }}\right)=\mathrm{M}_{\mathrm{ext}}\left(\frac{M J}{\text { tourist }}\right)+\left(\left[M_{\text {int }}\left(\frac{M J}{\text { tourist } \cdot \text { day }}\right)+\mathrm{S}_{\mathrm{ec}}\left(\frac{M J}{\text { tourist } \cdot \text { day }}\right)\right] \cdot\right.$ Stay length $($ days $\left.)\right)$

(4) $E C_{d}\left(\frac{M J}{\text { tourist.day }}\right)=\frac{\mathrm{EC}\left(\frac{M J}{\text { tourist.trip }}\right)}{\text { Stay length (days) }}$

(5) $E C_{b a}\left(\frac{M J}{\text { tourist } \cdot \text { trip } \cdot h a}\right)=\frac{E C\left(\frac{M J}{\text { tourist trip }}\right)}{\text { Built area (ha) }}$

(6) $E C_{\text {oa }}\left(\frac{M J}{\text { tourist } \cdot \text { trip } \cdot h a}\right)=\frac{\mathrm{EC}\left(\frac{M J}{\text { tourist:trip }}\right)}{\text { Tourist hub area (ha) }}$

\section{Results and discussion}

\subsection{Tourist hub characterization}

As a first step the tourist hubs were characterized according to data gathered during the field work. This initial characterization highlighted the need classify the different hubs 
into three groups according to the differences in land use distribution (Figure 3). Classification was based on the concentration of regulated tourist accommodations (i.e., hotels, apartments): Hotel hubs, with more than $30 \%$ of the surface used for regulated tourist accommodations; Residential hubs, with $<10 \%$ of the surface used for regulated tourist accommodations; and Mixed hubs, with between 10 and $30 \%$ of the surface used for regulated tourist accommodations. Land use distribution analysis also quantifies the heterogeneity of the selected tourist hubs (Figure 3). From the most compact and touristic area (Cala en Bosch, $>40 \%$ of regulated accommodations) to the most diffuse and residential area (Binibèquer Nou, 0\%), some common and divergent characteristics can be observed. The hubs have reduced commercial and service soil area $(<3 \%)$, apart from Son Parc, which has a golf pitch $(\approx 20 \%)$, and Cala Morell and Binibéquer Nou, which have few of these facilities $(<0.2 \%)$. These land use characteristics resulted in determining factors for the energy metabolism of each tourist hub.

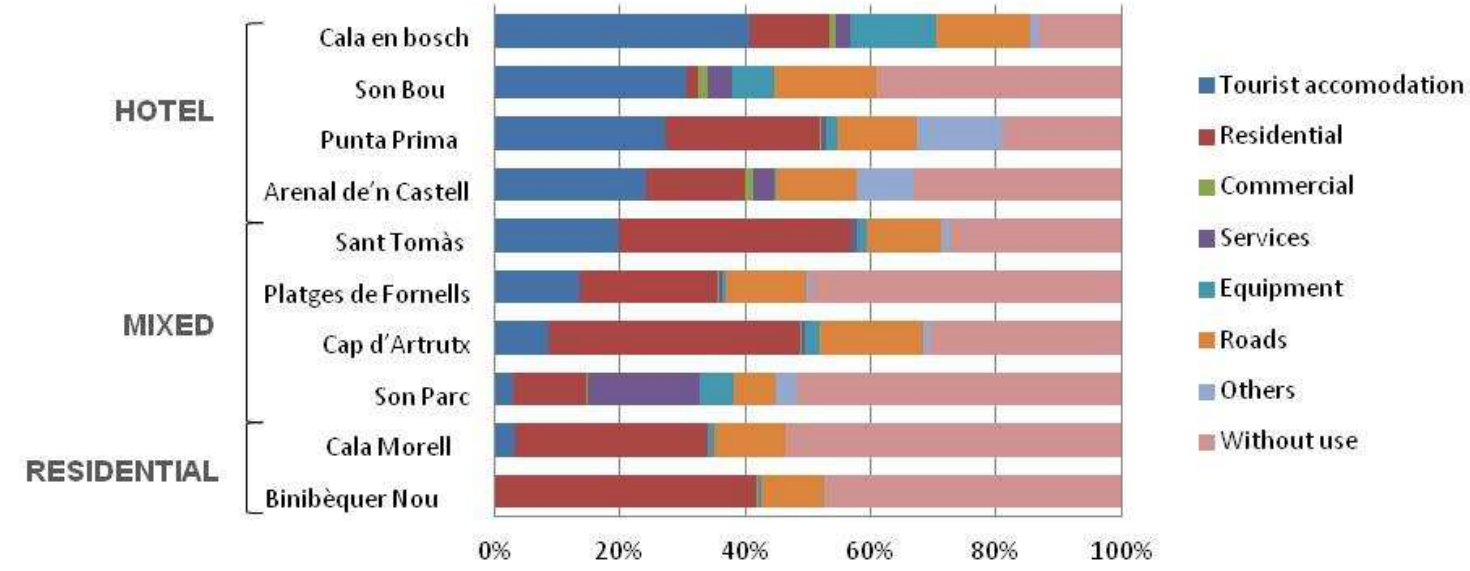

Figure 3. Land use distribution of the 10 selected tourist hubs. Tourist accommodation land use (in \%) was used as threshold for classifying the tourist hubs into hotel, mixed or residential. 


\subsection{Tourist profile}

The tourist surveys resulted in a user characterization for each hub (Table 3). On average, tourists come mainly from Spain (39\%) and the United Kingdom (37\%), a distribution that agrees with the most recent Menorca tourism statistics (OBSAM, 2010). However, Spanish tourists tend to concentrate in residential hubs (representing 55.5\%), while UK tourists concentrate in hotel hubs (43\%). Other nationalities have a lesser presence, with the most important being Italy (9\%) and Germany (5\%). The distribution of these minority nationalities $(<10 \%)$ is irregular, especially in hotel and mixed hubs. However, concentration phenomena occur in some cases, such as at Son Bou $(9 \%$ from Portugal), Cala en Bosch ( $7 \%$ from The Netherlands) and Binibèquer Nou ( $5 \%$ from Switzerland). Furthermore, tourists that visit Menorca for the first time frequent hotel hubs (46\%) more than in residential ones (17\%).

Regarding the use of lodging services, holiday packages are not usually booked (61\% on average), specifically in residential hubs (97\%) where second homes are common. All-inclusive holiday packages are the most booked packages in hotel hubs (27\%) and mixed hubs (18\%), followed by half board ( $8.7 \%$ on average) and only accommodation packages $(7.6 \%)$. This fact is related to the presence of accommodation services and tourism facilities (e.g., golf) that promote the booking of holiday packages. Finally, the average length of stay is also linked to the type of tourist hub; residential tourist stays last an average of almost 27 days, while hotel hubs have an average stay of only 16 days.

Mobility patterns were also shown to be related to the type of hub. Most tourists of hotel hubs $(93 \%)$ use a plane to reach the island, while ship use is highest for tourists of residential hubs $(27 \%)$. The external mobility mode of transport is mainly chosen based 
on the distance from the origin and is longer for hotel hubs (1941 km). Moreover, ship use is higher in tourist hubs where Spanish, French or Italian tourists are most common (i.e., residential hubs). However, trends are the opposite in internal mobility. Tourists in residential hubs travel more (48\%), and the associated distances are larger $(26 \mathrm{~km}$ daily) than for the other hubs. Moreover, private transportation is more common for this type of hub than in hotel hubs (where bus accounts for almost $40 \%$ of the internal mobility). On average, internal mobility was more intense $(21.6 \mathrm{~km})$ than tourism-related mobility at the country level, such as in Norway (17 km) (Høyer, 2000). However, the presence of cars (58\%) is lower than in other islands, such as Lanzarote where $77 \%$ of the mobility is performed by car (Martín-Cejas \& Ramírez, 2010).

Table 3. Tourist profile for the different tourist hubs analysed, according to origin, booking of lodging services, average length of the stay and external and internal mobility.

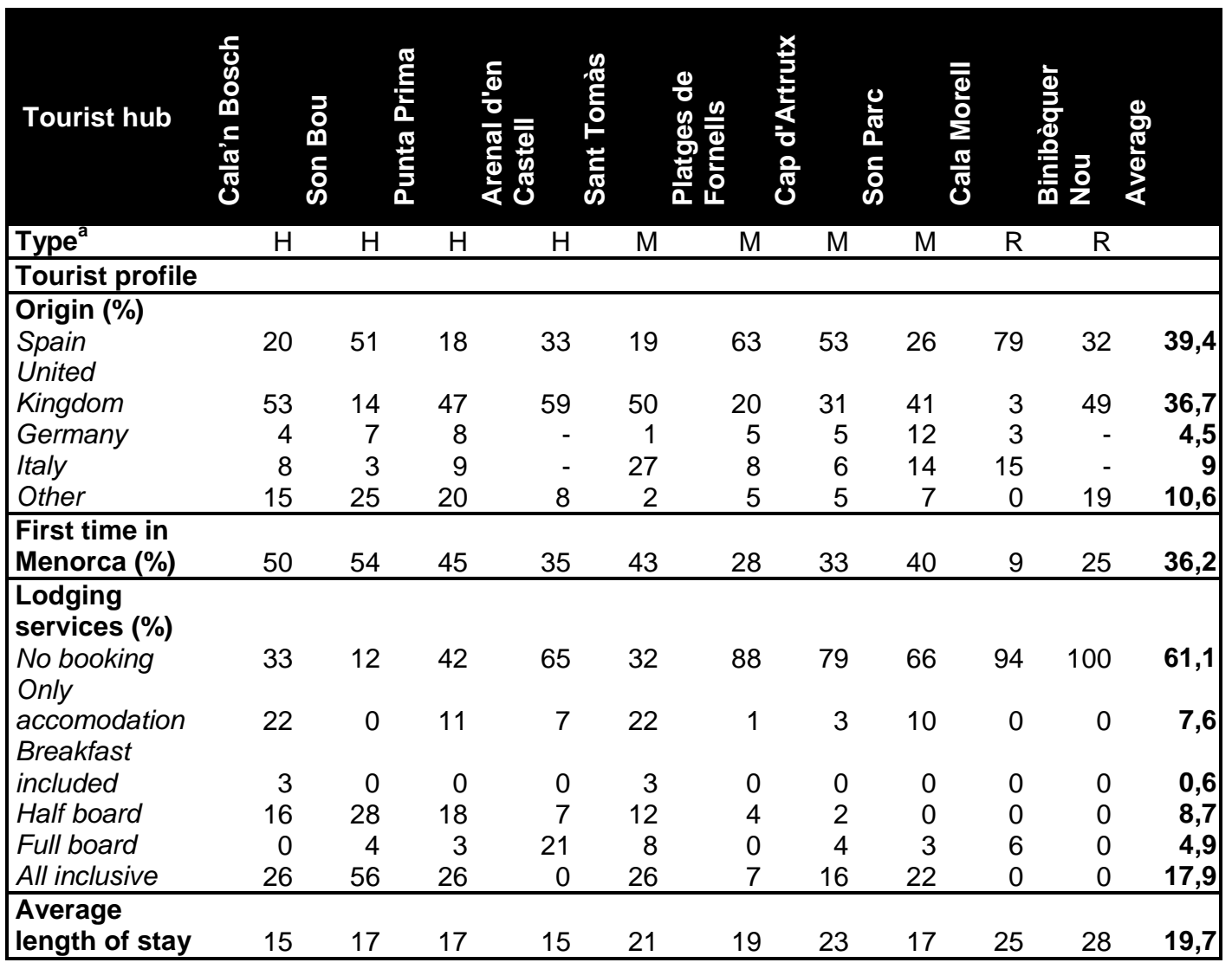




\begin{tabular}{|c|c|c|c|c|c|c|c|c|c|c|c|}
\hline (days) & & & & & & & & & & & \\
\hline $\begin{array}{l}\text { External } \\
\text { mobility } \\
\text { Trip to } \\
\text { Menorca (\%) }\end{array}$ & & & & & & & & & & & \\
\hline - By plane & 94 & 100 & 91 & 87 & 96 & 66 & 73 & 84 & 54 & 94 & 83,9 \\
\hline - By ship & & 0 & 9 & 13 & 4 & 34 & 27 & 16 & 46 & 6 & 16,1 \\
\hline Average & 1594 & 1327 & 2473 & 2371 & 2405 & 1624 & 1093 & 1594 & 2305 & 1463 & \\
\hline distance $(\mathrm{km})$ & \pm 689 & \pm 756 & \pm 961 & \pm 1169 & \pm 900 & \pm 1564 & \pm 717 & \pm 689 & \pm 976 & \pm 688 & 1824,9 \\
\hline $\begin{array}{l}\text { Internal } \\
\text { mobility } \\
\text { Tourists who }\end{array}$ & & & & & & & & & & & \\
\hline $\begin{array}{l}\text { travel (\%) } \\
\text { Mean of } \\
\text { transportation } \\
(\%)\end{array}$ & 38 & 32 & 33 & 25 & 28 & 77 & 41.4 & 42 & 58 & 38 & 37,1 \\
\hline - Own car & 10 & 5 & 17 & 18 & 11 & 40 & 42 & 21 & 76 & 32 & 27,2 \\
\hline - Rental car & 24 & 23 & 20 & 24 & 38 & 42 & 30 & 34 & 18 & 56 & 30,9 \\
\hline - Bus & 34 & 39 & 50 & 34 & 31 & 15 & 25 & 22 & 9 & 18 & 27,7 \\
\hline - Taxi & 7 & 11 & - & - & - & - & 13 & - & 6 & 14 & 5,1 \\
\hline - Bycicle & 6 & 0 & - & - & - & - & 5 & - & 15 & 4 & 3 \\
\hline Average & & & & & & & & & & & \\
\hline distance $(\mathrm{km})$ & 20 & 16 & 15 & 14 & 14 & 39 & 24 & 22 & 34 & 18 & 21,6 \\
\hline
\end{tabular}

${ }^{a}$ Tourist hubs are classified by typologies: Hotel [H], Mixed [M] and Residential [R]

\subsection{Energy and environmental metabolism}

The energy consumption per tourist and trip varies depending on the tourist hub analyzed, and ranges from $3418 \mathrm{MJ}$ (Platges de Fornells) to almost $6800 \mathrm{MJ}$ (Son Bou). On average, this value is larger in residential hubs ( $5900 \mathrm{MJ})$ than in other types of tourist hubs $(<5000 \mathrm{MJ})$ (Table 4). However, patterns are different regarding the flow where energy is consumed. The contribution of external mobility to the energy consumption is higher in hotel hubs, which concentrate more international tourists that have traveled greater distances. Moreover, in residential hubs the use of ships is more common, decreasing the energy input per passenger, as it is a transport option for countries significantly closer to the island, such as Spain ( 40\%) and Italy ( 5\%). By contrast, tourists in residential hubs consume more energy for daily internal mobility because they travel by car. In addition, the daily distances are larger because residential hubs have lower availability of services $(<0.2 \%$ of land use) and equipment $(<2.5 \%)$. This contrasts with hotel hubs (up to $9 \%$ of services and up to $15 \%$ of 
equipment). Moreover, mixed and residential hubs are more territorially dispersed. Therefore, tourists in hotel hubs tend to stay in the same town or nearby while covering smaller distances $(16 \mathrm{~km})$ than tourists in mixed $(25 \mathrm{~km})$ and residential $(26 \mathrm{~km})$ hubs. In agreement with this, the consumption during the stay is larger in residential hubs due to the facilities availability to tourists in houses, as opposed to staying in a hotel. The contribution of external mobility to the total energy consumption ( $67 \%$ on average) was higher than in other island scale analyses: $<63 \%$ in different islands of Taiwan (Kuo et al., 2012).

On the other hand, daily energy consumption per tourist showed a different trend than the per trip energy consumption. A tourist in a hotel hub consumes more energy ( 300

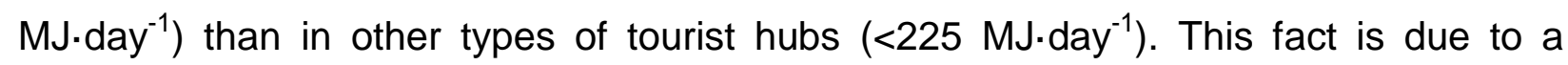
shorter stay of tourists in hotel hubs. Although hotel hub tourists have a lower daily consumption (internal mobility and during the stay) the overall consumption per day is larger when accounting for external mobility. Notwithstanding the lower consumption in external mobility, the daily consumption patterns accounted for the largest energy consumption per trip due to a longer stay in residential hubs. Finally, energy consumption indicators per area (both built and overall area) were higher for hotel hubs, which are denser than mixed and residential hubs (characterized by dispersed construction). Moreover, hotel hubs have a land use intensity higher (13\% on average) than mixed (9\%) and residential (7\%), according to the built and total area ratios. The consumption per day lies within the patterns observed in other islands, the tourism energy use per day in some Taiwan islands is between 118 and $502 \mathrm{MJ}$ (Kuo et al., 2012) and is similar to other tourist areas, such as the West Coast of New Zealand (341 MJ per tourist and day) (Becken et al., 2003). 
The environmental assessment showed that the carbon footprint of a tourist on the island of Menorca is $14.6 \mathrm{~kg} \mathrm{CO}_{2}$ per day on average (Table 4). Much of the emissions are associated with the external mobility (trip to the island) $(77.7 \%)$ due to air travel. This value is higher than the estimated contribution in the global market (59\%) (Peeters and Dubois, 2010), although it is closer to the contribution of air transport to global tourism GHG emissions for Switzerland (80\%) (Perch-Nielsen et al., 2010). The carbon footprint is thus reduced for tourists whose origins are closer to the island (such as tourists from Spain), while it is increased for those farther away (such as tourists from the United Kingdom). The type of transport to the tourist hub also influences the associated emissions of $\mathrm{CO}_{2}$. For example, the impact of traveling to Cala Morell from Barcelona may be different by $15 \%$ depending on whether the trip to the island is made by plane $\left(56 \mathrm{~kg} \mathrm{CO}_{2}\right.$ ) or boat $\left(48 \mathrm{~kg} \mathrm{CO}_{2}\right)$. Regarding the type of tourist hub, a tourist in Menorca has the lowest carbon footprint by staying in a mixed hub $\left(248.1 \mathrm{~kg} \mathrm{CO}_{2}\right)$. In contrast, tourists in residential hubs have the highest $\mathrm{CO}_{2}$ contribution per stay (321.5 $\mathrm{kg} \mathrm{CO}_{2}$ ) because the stay is typically longer and internal mobility is higher. Hotel hubs have an associated carbon footprint of $284.7 \mathrm{~kg} \mathrm{CO}_{2}$ per tourist per trip, although they show the highest contributions per day $\left(\sim 17 \mathrm{~kg} \mathrm{CO}_{2} \cdot\right.$ day $\left.^{-1}\right)$, followed by mixed hubs $\left(\sim 12 \mathrm{~kg} \mathrm{CO}_{2} \cdot \mathrm{day}^{-1}\right)$ and residential hubs $\left(\sim 12 \mathrm{~kg} \mathrm{CO}_{2} \cdot \mathrm{day}^{-1}\right)$ hubs (Table 4$)$.

Therefore, this assessment has revealed strong relationships between the energy and environmental metabolism and 1) the type of tourist hub and 2) the user profile. The type of tourist hubs was determined based on the type of tourist services and the promotion of holiday packages, the availability of services and equipment in the area and the morphology of the settlements. The user profile was primarily determined based on origin of the tourist, the use of public or private transportation, and the length of the stay. 


\subsection{Self-sufficiency assessment for power generation in tourist hubs}

The available surface potential for installation of photovoltaic systems, obtained from GIS, adds up to 54 ha for all analyzed tourist hubs, but is unevenly distributed across hub types (from 2.2 to 8.2 ha) (Table 4). The residential hubs have higher potential (61\% of total) than hotel hubs $(20 \%)$, which are dominated by vertical (high-rise) buildings. Considering the balance between energy production and consumption during tourist stays, residential areas would net a positive balance throughout the year due to the availability of a large solar collector area and the resulting production potential. Hotel hubs would have a positive balance for only four or five months per year, as they have high power consumption combined with a small roof surface area upon which to install photovoltaic panels due to the compact morphology. Finally, the mixed hubs would have a positive balance for nine to ten months per year; their consumption is not as high as in hotel hubs, and they have smaller potential areas for the installation of photovoltaic systems than residential hubs. For all tourist hub types, self-sufficiency values are positive considering the potential annual photovoltaic production, representing an energy surplus of 387,000 GJ per year. The strategy of moving to photovoltaic energy production could yield power self-sufficiency potential between 122 and $1,144 \%$ of the current potential in the tourist hub (Table 4).

The photovoltaic production potential may also represent a reduction in the $\mathrm{CO}_{2}$ emissions associated with coastal tourist hubs by supplying the electricity consumption during tourist visits. The monthly savings of $\mathrm{CO}_{2}$ emissions is estimated at an average of 7 tons per tourist hub (Table 4). Additionally, the extra production of electricity could also feed the demands of the entire island beyond just the tourist hubs if it were injected into the island electrical network. The extra production of electricity would replace 
electricity from non-renewable sources because most of the energy comes from power plants fueled primarily by diesel (REE, 2012), thereby reducing the $\mathrm{CO}_{2}$ emission factor of the island mix (currently $1.06 \mathrm{~kg} / \mathrm{kWh}$ ).

Despite the potential production values, the installation of photovoltaic generation systems often encounters resistance in residential areas. In these areas tourist hubs are fragmented with a large number of private owners who are independent from each other, which requires a high degree of collaboration among users. In contrast, solar installation is often more straightforward in hotel hubs due to consolidated decisionmaking; typically a single manager serves an entire building or even groups of buildings.

Table 4: Energy requirements, $\mathrm{CO}_{2}$ emissions and self-sufficiency potential, by tourist hub.

\begin{tabular}{|c|c|c|c|c|c|c|c|c|c|c|c|}
\hline Tourist hub & 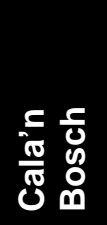 & $\begin{array}{c}\text { o̊ } \\
\text { m } \\
\text { co }\end{array}$ & 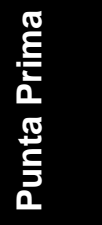 & 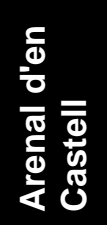 & 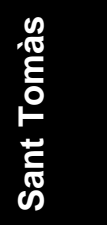 & 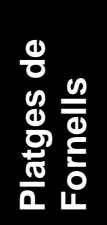 & 응 & 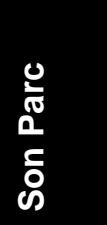 & $\begin{array}{l}\overline{\bar{\Phi}} \\
\overline{0} \\
\frac{\Phi}{\bar{D}} \\
0\end{array}$ & 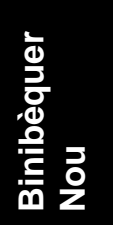 & 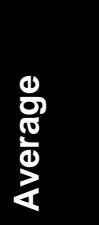 \\
\hline Type & $\mathrm{H}$ & $\mathrm{H}$ & $\mathrm{H}$ & $\mathrm{H}$ & M & M & M & M & $\mathrm{R}$ & $\mathrm{R}$ & \\
\hline $\begin{array}{l}\text { Average length } \\
\text { of stay (days) }\end{array}$ & 15 & 17 & 17 & 15 & 21 & 19 & 23 & 17 & 25 & 28 & 20 \\
\hline $\begin{array}{l}\text { Energy } \\
\text { consumption } \\
\text { - MOBILITY }\end{array}$ & & & & & & & & & & & \\
\hline$M_{\text {ext }}(M J /$ tourist $)$ & 3708,0 & 5389,2 & 3153,6 & 3132,0 & 3175,2 & 2192,4 & 2865,6 & 2937,6 & 1630,8 & 3855,6 & 3204,0 \\
\hline $\begin{array}{l}M_{\text {int }}(M J / \text { tourist) } \\
\text { - STAY } \\
\text { Lodging }\end{array}$ & 702,0 & 613,7 & 183,6 & 108,0 & 226,8 & 547,2 & 1324,8 & 244,8 & 1980,0 & 1209,6 & 714,1 \\
\hline $\begin{array}{l}\text { (MJ/tourist) } \\
\text { - TOTAL } \\
\text { EC }\end{array}$ & 1026,0 & 795,6 & 673,2 & 270,0 & 487,2 & 678,3 & 993,6 & 306,0 & 2340,0 & 806,4 & 837,6 \\
\hline $\begin{array}{l}\text { (MJ/tourist-trip) } \\
\mathbf{E C}_{\mathrm{d}}\end{array}$ & 5436,0 & 6798,5 & 4010,4 & 3510,0 & 3889,2 & 3417,9 & 5184,0 & 3488,4 & 5950,8 & 5871,6 & 4755,7 \\
\hline $\begin{array}{l}\text { (MJ/tourist·day) } \\
\mathrm{EC}_{\mathrm{ba}}\end{array}$ & 362,4 & 399,9 & 235,9 & 234,0 & 185,2 & 179,9 & 225,4 & 205,2 & 238,0 & 209,7 & 247,6 \\
\hline $\begin{array}{l}\text { (MJ/tourist.trip.ha) } \\
\mathbf{E C}_{\text {oa }}\end{array}$ & 856,6 & 3242,8 & 464,4 & 730,2 & 755,7 & 699,7 & 690,0 & 389,7 & 1573,2 & 686,7 & 1008,9 \\
\hline (MJ/tourist-trip.ha) & 143,7 & 403,4 & 54,7 & 93,2 & 85,8 & 66,9 & 81,9 & 15,3 & 85,1 & 61,0 & 109,1 \\
\hline $\begin{array}{l}\mathrm{CO}_{2} \text { emissions } \\
\text { - MOBILITY }\end{array}$ & & १२1 & 2516 & 2490 & 2541 & 1729 & 1380 & 2346 & 1225 & 2408 & 2156 \\
\hline $\begin{array}{l}M_{\text {int }}\left(\mathrm{kgCO} \mathrm{CO}_{2} / \text { tourist }\right) \\
\text { - STAY }\end{array}$ & 21,0 & $\begin{array}{r}2<1,0 \\
35,7\end{array}$ & $\begin{array}{r}251,0 \\
17,0\end{array}$ & $\begin{array}{r}49,0 \\
16,5\end{array}$ & $\begin{array}{r}254,1 \\
21,0\end{array}$ & $\begin{array}{r}1 / 2,9 \\
39,9\end{array}$ & 62,1 & $\begin{array}{r}204,0 \\
20,4\end{array}$ & 177,5 & $\begin{array}{r}240,0 \\
39,2\end{array}$ & $\begin{array}{r}10,0 \\
45,0\end{array}$ \\
\hline
\end{tabular}




\begin{tabular}{|c|c|c|c|c|c|c|c|c|c|c|c|}
\hline $\begin{array}{l}\text { Lodging } \\
\text { (kgCO } \mathrm{KO}_{2} \text { tourist) }\end{array}$ & 21,0 & 15,3 & 13,6 & 6,0 & 10,5 & 13,3 & 20,7 & 6,8 & 47,5 & 16,8 & 17,2 \\
\hline $\begin{array}{l}\text { Trip emissions } \\
\text { (kgCO } \mathrm{KO}_{2} \text { /tourist } \cdot \text { trip) } \\
\text { Daily emissions }\end{array}$ & 313,1 & 272,7 & 282,1 & 270,9 & 285,0 & 226,3 & 220,0 & 261,1 & 346,9 & 296,2 & 277,4 \\
\hline (kgCO $\mathrm{C}_{2}$ tourist $\cdot$ day) & 20,9 & 16,0 & 16,6 & 18,1 & 13,6 & 11,9 & 9,6 & 15,4 & 13,9 & 10,6 & 14,6 \\
\hline $\begin{array}{l}\text { Self-sufficiency } \\
\text { potential } \\
\text { Potential PV area } \\
\text { (ha) }\end{array}$ & 6,1 & 2,2 & 7,2 & 4,3 & 4,7 & 3,7 & 6,4 & 7,8 & 3,3 & 8,2 & 5,4 \\
\hline $\begin{array}{l}\text { Suitable area (\%) } \\
\text { PV production }\end{array}$ & 16,8 & 12,7 & 9,0 & 11,5 & 10,4 & 7,6 & 12,1 & 3,3 & 4,9 & 10,3 & 9,9 \\
\hline $\begin{array}{l}\text { (MJ/year) } \\
\text { Hub consumption }\end{array}$ & 505,4 & 178,9 & 596,5 & 351,4 & 390,6 & 309,6 & 532,4 & 641,5 & 275,8 & 679,7 & 446,2 \\
\hline $\begin{array}{l}\text { (MJ/year) } \\
\text { Self-sufficiency }\end{array}$ & 318,2 & 146,2 & 225,4 & 119,9 & 157,7 & 133,9 & 122,0 & 99,4 & 103,7 & 59,4 & 148,6 \\
\hline $\begin{array}{l}\text { potential (\%) } \\
\text { Monthly avoided } \\
\mathrm{CO}_{2} \text { emissions } \\
\left(t \mathrm{CO}_{2} / \text { month) }\right.\end{array}$ & 159,0 & 122,0 & 265,0 & 293,0 & 248,0 & 231,0 & 436,0 & 645,0 & 266,0 & 1144,0 & 380,9 \\
\hline
\end{tabular}




\section{4. Conclusions and recommendations for managers}

3 The characterization of tourist hubs through GIS highlighted the

4 heterogeneity of the sample and enabled their categorization into three

5 groups based on the percentage of the surface used for regulated tourist

6 accommodations: hotel hubs (>30\%), residential hubs $(<10 \%)$ and mixed

7 hubs (between 10 and 30\%). Moreover, land use issues highlighted

8 differences among these hub types that demonstrated the importance of

9 considering these tourist aggregations as an entire system. For example,

10 compared with residential hubs, the hotel hubs have a significantly higher

11 percentage of land used for services, facilities and shops. Although all the

12 tourist hubs showed a lower permanent occupation and, therefore, an

13 underuse of their infrastructures, it occurs more prominently in hotel hubs

$14(3.9 \%)$ than in residential hubs $(20.5 \%)$.

15 Energy metabolism depends on the tourist profile (based on origin, use of

16 public transportation, and length of stay) and the type of tourist hub (based

17 on type of tourist services, availability of services, and morphology). On

18 average, a tourist consumes 4,756 MJ with associated emissions of 277

$19 \mathrm{~kg}$ of $\mathrm{CO}_{2}$ per stay (20 days on average), although depending on the type

20 of tourist hub this consumption per trip ranges from $\sim 4,000 \mathrm{MJ}$ (mixed

21 hubs) to $\sim 6,000$ MJ (residential hubs). Self-sufficiency in power

22 consumption for lodging services could satisfy $100 \%$ of tourist

23 consumption, as well as offer potential benefits to the entire island. By

24 installing solar panels, the tourist hubs could achieve energy self- 
25 sufficiency. Residential hubs could achieve energy self-sufficiency

26 throughout the entire year, while mixed hubs could achieve energy self-

27 sufficiency only between 7 and 10 months per year. In addition, Menorca

28 Island could increase the percentage of renewable energy contribution to

29 the power mix, and could avoid the occupation of fertile areas by solar

30 farms by taking advantage of rooftops.

31 This assessment showed that public authorities (policymakers) and the

32 managers of lodging services might play an important role in the

33 development of a sustainable tourism management approach. With regard

34 to tourist energy consumption, public government and policymakers

35 should encourage business managers and private property owners

36 towards the installation of energy-efficient facilities (e.g., low-energy

37 appliances and systems) as well as photovoltaic generation systems or

38 other renewable energy sources. The promotion of renewable energy

39 would not only impart positive effects for the tourist facilities, but potentially

40 for Menorca as a whole, which could take advantage of the cleaner energy

41 source during the offseason and by utilizing any energy surplus, thus

42 reducing the environmental burden of the current electricity mix.

43 Policymakers could promote tax incentive policies or develop investment

44 programs for implementing solar energy; likewise, business managers

45 might prioritize the use of renewable energies and enjoy energy savings

46 by investing in their buildings. Most common interventions for achieving

47 energy efficiency in hotels where identified in Beccoli et al. (2009) for Italy

48 as the following: retrofit of building envelopes, retrofit of heating plants,

49 use of high efficiency appliances, installation of tri-generation plants, use 
50 of active solar systems for DHW and use of photovoltaic systems. Finally,

51 the creation of a best practices code or manual could be a useful tool to

52 improve the knowledge base of managers.

53 In terms of transportation, policymakers could promote the use of sea

54 travel among tourism company operators as the most environmentally

55 friendly method of transit for external trips (e.g., reduction of $15 \%$ per trip

56 for a tourist from Barcelona). This could also result in positive effects for

57 tourists from nearby Mediterranean countries (e.g., Spain, France, Italy).

58 Once a tourist is on the island, energy consumption of internal mobility

59 could be reduced by promoting public transportation. Public authorities

60 might invest in improving the current services and infrastructures; as

61 shown in the OBSAM's indicator system (Fullana et al., 2010), public

62 transport currently has low usage rates due to the lack of comprehensive

63 coverage of the entire island. Furthermore, the number of tourist services

64 (e.g., supermarkets and shops) could be increased near residential and

65 mixed hubs to shorten the distances travelled during the tourists' stays

66 (e.g., at Cala Morell, no services are available) and therefore reduce

67 emissions associated with shopping trips.

68 Environmental information could be useful for tourists as well and this

69 issue should be considered by local policy makers. The introduction of an

70 ecolabeling system for tourist accommodations could promote more

71 sustainable tourism, which might confer added value to the higher scoring

72 accommodations if incorporating an environmental variable into the

73 decision-making processes of the tourists resulted in increased choices of 
74 more ecologically responsible businesses. Both public authorities and

75 business managers could be included in a process to agree on the design

76 of a tourist ecolabel incorporating environmentally related metrics for the

77 different tourist hubs, lodging services or holiday packages across the

78 island.

79 Finally, both public and private stakeholders could be responsible for

80 promoting greater environmental awareness (Valls and Sardà, 2009)

81 about the impacts of tourism energy use by developing environmental

82 education campaigns about the optimization of energy consumption (e.g.,

83 in the lodging services) and the benefits of using public transportation.

84 Awareness could also be promoted by tourist companies by integrating

85 environmental information in tourism promotions and in marketing

86 documentation.

\section{Acknowledgements}

89 The authors would like to thank the Observatori Socioambiental de

90 Menorca (OBSAM) and Institut Menorquí d'Estudis (IME) for the financial

91 support, as well as the the Spanish Ministerio de Educación for awarding

92 research scholarships to Esther Sanyé Mengual (AP2010-4044).

\section{References}

95 Agell, M., Bastardas. A., Cases, N., Riera, L., Perez, M., Carreras, D., Boada, M., Duch, 96 J., Sánchez, J.A., Rieradevall, J., 2011. Anàlisis dels fluxos d'energia, aigua i mobilitat a 
97 cinc nuclis turístics de Menorca. Final degree project. Universitat Autònoma de

98 Barcelona, Cerdanyola del Vallès, Spain.

99 Apostolopoulos, Y., Gayle, D.J., 2002. Island tourism and sustainable development:

100 Caribbean, Pacific and Mediterranean experiences. Praeger Publishers, Westport.

101 Ayres, R.U., Ayres, L.W., 2002. A handbook of industrial ecology. Edward Elgar

102 Publishing, Massachussetts, USA.

103 Beccali, M., La Gennusa, M., Lo Coco, L., Rizzo, G., 2009. An empirical approach for

104 ranking environmental and energy saving measures in the hotel sector. Renewable

105 energy, 34(1), 82-90.

106 Becken, S., Simmons, D.G., Frampton, C., 2003. Energy use associated with different

107 travel choices. Tourism Management, 24, 267-277.

108 Cànoves, G., Villarino, M., Priestley, G.K., \& Blanco, A., 2004. Rural tourism in Spain: an

109 analysis of recent evolution. Geoforum, 35(6), 755-769.

110 Chambers, T., 2004. Environmental assessment of a mass tourism package holiday and

111 a responsible tourism package holiday, using life cycle assessment and ecological

112 footprint analysis. Master degree thesis, University of East Anglia, Norwich, UK.

113 De Camillis, C., Petti, L., Raggi, A., 2008. LCA: a key-tool for sustainable tourism?

114 Proceedings of the 8th international conference on EcoBalance, Tokyo, Japan, 10-12

115 December 2008, pp 485-488.

116 Deyà Tortella, B., Tirado, D., 2011. Hotel water consumption at a seasonal mass tourist

117 destination. The case of the island of Mallorca. Journal of Environmental Management, 118 92(10), 2568-79.

119 Dones, R., Bauer, C., Bolliger, R., Burger, B., Faist Emmenegger, M., Frischknecht, R.,

120 Heck, T., Jungbluth, N., Röder, A., 2007. Life Cycle Inventories of Energy Systems:

121 Results for Current Systems in Switzerland and other UCTE Countries. Final report

122 ecoinvent data v2.0, No. 5. Swiss Centre for Life Cycle Inventories, Dübendorf. 
123 Farreny, R., Oliver-Solà, J., Lamers, M., Ameling, B., Gabarrell, X., Rieradevall, J.,

124 Boada, M., Benayas, J., 2011. Carbon dioxide emissions of Antarctic tourism. Antarctic

125 Science, 23(6), 556-566.

126 Fullana, A., 2005. Evolución de la población de Menorca a finales de siglo XX. Incidencia

127 de la actividad turística en su desarrollo. Cuadernos Geográficos, 36, 307-317.

128 Fullana, J., Estradé, S., Gallofré, A., Pérez, M., Marsinyach, E., Carreras, D., Julià, M.,

129 Ranalli, M., Fernández, I., Masana, D., Mir, M., 2010. Sistema d'Indicadors del Pla

130 Territorial Insular -Informe 2010. Consell Insular de Menorca, Maó.

131 Giorgi, F., 2006. Climate change hot-spots. Geophysical Research Letters, 33(8), art. no.

132 L08707.

133 Giorgi, F., Lionello, P., 2006. Climate change projections for the Mediterranean region.

134 Global and Planetary Change, 63(2-3), 90-104.

135 Gössling, S., 2002. Global environmental consequences of tourism. Global

136 Environmental Change, 12(4), 283-302.

137 Gössling, S., Borgstrom Hansson, C., Horstmeier, O., Saggel, S., 2002. Ecological

138 footprint analysis as a tool to assess tourism sustainability. Ecological Economics, 43,

139 199-211.

140 Groves, R.M., Fowler, F.J., Couper, M.P., Lepkowski, J.M., Singer, E., Tourangeau, R.,

141 2009. Survey Methodology. John Wiley \& Sons, New Jersey.

142 Hadjikakou, M., Chenoweth, J., Miller, G., 2013. Estimating the direct and indirect water

143 use of tourism in the eastern Mediterranean. Journal of Environmental Management, 114, 144 548-556.

145 Hein, L., Metzger, M.J., \& Moreno, A., 2009. Potential impacts of climate change on

146 tourism; a case study for Spain. Current Opinion in Environmental Sustainability,

$1471(2), 170-178$.

148 Hickman, J., Hassel, D., Joumard, R., Samaras, Z., Sorenson, S., 1999. Methodology for

149 calculating transport emissions and energy consumption. Transport Research Laboratory,

150 Crowthorne. 
151 Honey, M., Krantz, C., 2007. Global trends in coastal tourism. Center on Ecotourism and

152 Sustainable Development, Washington DC.

153 Høyer, K.G., 2000. Sustainable Tourism or Sustainable Mobility? The Norwegian Case.

154 Journal of Sustainable Tourism, 8(2), 147-160.

155 Hunter, C., Shaw, J., 2007. The ecological footprint as a key indicator of sustainable

156 tourism. Tourism Management, 28(1), 46-57.

157 ICAO, 2012. Carbon emissions calculator. Version 5. Available on:

158 http://www.icao.int/environmental-protection/CarbonOffset/Pages/default.aspx (Accessed

159 September 2011)

160 IDAE, 2002a. Instalaciones de Energía Solar Fotovoltaica, menores de 5kW, conectadas

161 a red. Instituto para la Diversificación y Ahorro de la Energía, Madrid.

162 IDAE, 2002b Instalaciones de Energía Solar Fotovoltaica. Pliego de Condiciones

163 Técnicas de Instalaciones Conectadas a Red. Instituto para la Diversificación y Ahorro de

164 la Energía, Madrid.

165 IDAE, 2006. Manuales energías renovables: energía solar térmica. Instituto para la

166 Diversificación y Ahorro de la Energía, Madrid.

167 IDAE, 2010a. Guía de vehículos de venta en España, con indicación de consumos y

168 emisiones de $\mathrm{CO}_{2}$. Instituto para la Diversificación y Ahorro de la Energía, Madrid.

169 IDAE, 2010b. Factores de conversión a energía primaria (ep) y factor de emisión de $\mathrm{CO}_{2}$

170 para carburantes, usos térmicos y electricidad. Instituto para la Diversificación y Ahorro

171 de la Energía, Madrid.

172 IPCC, 2007. Climate Change 2007: Synthesis Report. Contribution of Working Groups I,

173 II and III to the Fourth Assessment. Report of the Intergovernmental Panel on Climate

174 Change [Core Writing Team, Pachauri, R.K, Reisinger, A. (eds.)]. IPCC, Geneva.

175 Kahn Ribeiro, S., Kobayashi, S., Beuthe, M., Gasca, J., Greene, D., Lee D.S.,

176 Muromachi, Y., Newton, P.J., Plotkin, S., Sperling, D., Wit, R., Zhou, P.J., 2007.

177 Transport and its infrastructure, in: Metz, B., Davidson, O.R, Bosch, P.R., Dave, R.,

178 Meyer, L.A. (Eds.), Climate Change 2007: Mitigation. Contribution of Working Group III to 
179 the Fourth Assessment Report of the Intergovernmental Panel on Climate Change.

180 Cambridge University Press, Cambrigde, pp. 323-386.

181 König, H., Schmidberger, E., De Cristofaro L., 2007. Life cycle assessment of a tourism

182 resort with renewable materials and traditional construction techniques, in: Bragança, L.,

183 Pinheiro, M.D., Jalali, S., Mateus, R., Amoêda, R., Guedes, M.C. (Eds), Portugal SB07,

184 Sustainable construction, materials and practices. IOS Press, Amsterdam.

185 Kuo, N.W., Chen, P.H., 2009. Quantifying energy use, carbon dioxide emission, and

186 other environmental loads from island tourism based on a life cycle assessment

187 approach. Journal of Cleaner Production, 17(15), 1324-1330.

188 Kuo, N.W., Lin, C.Y., Chen, P.H., Chen, Y.W., 2012. An inventory of the energy use and

189 carbon dioxide emissions from island tourism based on a life cycle assessment approach.

190 Environmental progress \& Sustainable energy, 31(3), 459-465

191 La Gennusa, M., Lascari, G., Rizzo, G., Scaccianoce, G., Sorrentino, G., 2011. A

192 modelfor predicting the potential diffusion of solar energy systems in complex urban

193 environments. Energy Policy, 39(9), 5335-5343

194 Lu, W., Stepchenkova, S., 2012. Ecotourism experiences reported online: Classification

195 of satisfaction attributes. Tourism Magement, 33(3), 702-712.

196 Manila declaration on world tourism, 1980. World tourism conference. Available in:

197 http://www.univeur.org/CMS/UserFiles/65.\%20Manila.PDF [Accessed 5 April 2013]

198 Marion, B., Adelstein, J., Boyle, K., Hayden, H., Hammond, B., Fletcher, T., Canada, B.,

199 Narang, D., Shugar, D., Wenger, H., Kimber, A., Mitchell, L., Rich, G., Townsend, T.,

200 2005. Performance Parameters for Grid-Connected PV Systems. National Renewable

201 Energy Laboratory, Golden.

202 Martín-Cejas, R.R., Ramírez, P.P., 2010. Ecological footprint analysis of road transport

203 related to tourism activity: The case for Lanzarote Island. Tourism Management, 31, 98-

204103

205 Montaner Montejano, J., 1991. Estructura del mercado turístico. Síntesis, Madrid. 
206 Oficina de Canvi Climàtic, 2011. Guia pràctica per al càlcul d'emissions de gasos amb

207 efecte d'hivernacle (GEH), Versió 2011. Comissió Interdepartamental del Canvi Climàtic

208 de la Generalitat de Catalunya, Barcelona.

209 OSE, 2011. Sustainability in Spain - 2011 Report. Observatory of Sustainability in Spain,

210 Madrid.

211 OBSAM, 2010. Indicadors de sostenibilitat de l'illa de Menorca - Entrada de turistes.

212 Entrada de turistes segons nacionalitat 2001 - 2009. Institut Menorquí d'Estudis (IME),

213 Maó.

214 OBSAM, 2011. Indicadors de sostenibilitat de l'illa de Menorca - Consum d'electicitat

215 segons lloc i font de generació 1957 - 2010. Institut Menorquí d’Estudis (IME), Maó.

216 OBSAM, 2012. Indicadors de sostenibilitat de l'illa de Menorca - Consum d'electricitat

217 per municipis. Facturació. Institut Menorquí d’Estudis (IME), Maó.

218 OBSAM, 2009. Indicadors de sostenibilitat de l'illa de Menorca - Balanç global d'energia

219 a Menorca. Institut Menorquí d’Estudis (IME), Maó.

220 Papatheodorou, A., 2004. Exploring the evolution of tourism resort. Annals of Tourism

221 Research, 31(1), 219-37.

222 Peeters, P., Dubois, G., 2010. Tourism travel under climate change mitigation

223 constraints. Journal of Transport Geography, 18(3), 447-457.

224 Perry, A., 2006. Will Predicted Climate Change Compromise the Sustainability of

225 Mediterranean Tourism? Journal of Sustainable Tourism, 14(4), 367-375.

226 Petti, L., Tontodonati, S., 2002. The use of LCA as a tool to implement EPDs: an

227 application to hotel services. Proceedings of the fifth international conference on

228 Ecobalance, 6-8 November 2002, Tsukuba, Japan, pp 329-332.

229 PTI, 2003. Pla territorial insular de Menorca. Consell insular de Menorca, Maó.

230 PTI, 2006. Pla territorial insular de Menorca - Modificacions. Consell insular de Menorca, 231 Maó. 
232 Radulescu, C.V., 2011. Tourism and Environment - Towards a European Tourism Policy.

233 Journal of Knowledge Management, Economics and Information Technology, 1 (5), 66 -

23476.

235 REE, 2012. Energy demand in real time. Online application available on:

236 http://www.ree.es/operacion/curvas demanda.asp (Accessed June 2012)

237 Rees, W.E., 1992. Ecological footprints and appropriated carrying capacity: what urban

238 economics leaves out. Environment and Urbanisation, 4(2), 121-130.

239 Riera, A., Ripoll, A.M., Martínez, D., Herrón, A., 2009. Llibre Blanc del turisme de les illes

240 Balears. Cap a una nova cultura turística. Conselleria de Turisme, Govern de les Illes

241 Balears, Mallorca.

242 Sisman, K., 1994. A life-cycle analysis of a holiday destination: Seychelles. British

243 Airways environment report, vol. 41. UK CEED, Cambridge.

244 UNWTO, 2008. Climate change and tourism: responding to global challenges. World

245 Tourism Organization and the United Nations Environment Programme, Madrid.

246 UNWTO, 2012. UNWTO Tourism Highlights, 2012 Edition. World Tourism Organization,

247 Madrid.

248 Valls, J.F., Sardà, R., 2009. Tourism expert perceptions for evaluating climate change

249 impacts on the Euro-Mediterranean tourism industry. Tourism Review, 64(2), 41-51.

250 Weaver, D., Opperman, M., 2000. Tourism Management. John Wiley and Sons, New 251 York.

252 Weaver, D.B., Lawton, L.J., 2007. Twenty years on: The state of contemporary

253 ecotourism research. Tourism Management, 28, 1168-1179.

254 World Economic Forum, 2009. Towards a low carbon travel \& tourism sector. World

255 Economic Forum, Geneva.

257 Appendixes

258 Appendix 1: Survey to users 


\begin{tabular}{|c|c|c|c|}
\hline \multicolumn{2}{|l|}{ Date: } & Hour: & Survey №: \\
\hline \multicolumn{2}{|l|}{ Touristic hub: } & Accommodation type: & Accommodation name: \\
\hline $\begin{array}{l}\text { 1. Binibequer Nou } \\
\text { 2. Son Bou }\end{array}$ & $\begin{array}{l}\text { 3. Cala Morell } \\
\text { 4. Cap d'Artrutx } \\
\text { 5. Cala en Bosc }\end{array}$ & $\begin{array}{l}\text { 1. H_- (hotel, star rating) } \\
\text { 2. HA_- (hotel apartments, star rating) } \\
\text { 3. A_Cl (tourist apartment, rating) } \\
\text { 4. CV_Cl (halidays city, rate) }\end{array}$ & $\begin{array}{l}\text { 5. VLP (housing - private rental) } \\
\text { 6. VP (housing - own) } \\
\text { AL (others, specify) }\end{array}$ \\
\hline GENERAL INF & ORMATION & & \\
\hline
\end{tabular}

1. Country of origin and transport Country:

City:

$\begin{array}{lllll}\text { Transport: 1. Aeroplane } & \text { 2. Ferry } & \text { 3. Car } & \text { 4. Taxi } & \text { 5. Bus }\end{array}$

\begin{tabular}{|l|l|l|}
\hline Origin & Destination & Transport \\
\hline & & \\
\hline & & \\
\hline & & \\
\hline
\end{tabular}

2. Duration of the stay Date of arrival:

Date of departure:

N Nights:

3. Previous visits to Minorca

Is it the first time you hove visited Minorca?

Yes

No

$\mathrm{N}$ times

4. Reason of the trip. What are the main reasons to choose Minorca as a holiday destination?(max. 3 options)

\begin{tabular}{|l}
1 Nature, landscape \\
2 Sun and beach \\
3 Climate \\
4 Tranquillity (quiet) \\
5 Cultural and historic aspects
\end{tabular}

6 Night leisure
7 Sport activities
8 Nautical activities
9 Hotel quality
10 Other:.........................

5. Group (description, amount of people and ages). Indicote the trovel group, amount of people and ages. Group:

1 Alone

2 Couple

4 Friends

N of people

Ages

3 Family

5 Others

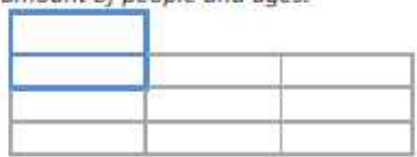

TOURIST AREA

6. Reason to choose the touristic accommodation. What is the main reason to choose this kind of accommodation?

1. Quality

2. Price

3. Services

4. Location

4. Other:
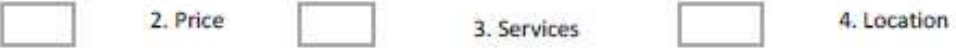

7. Tourist package. Did you book a tourist package?

No

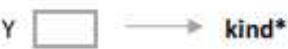

8. Awareness of the tourist area. How did you know about this tourist area?
1. Travel agency
2. Guide book
3. Internet
4. Advised by someone
4. Other:

9. Reason to choose the tourist area. What are the main reasons to choose the touristic nucleus where you stay? (max 3 options)
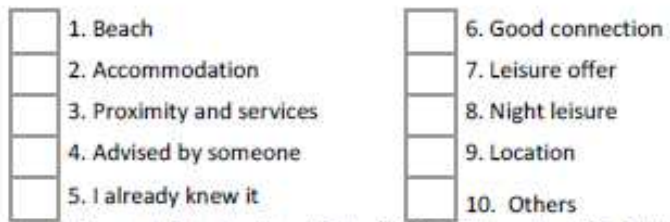

Kind*: 1. SA: only accommodation; 2. E: bed and breakfast; 3. MP: half board; 4. PC: full board; 5. $T 1$ : All inclusive 
The best thing:

The worst thing:

11. Visit the beach near the tourist area. Have you already visited the nearest beach?

No $\square$ Yes $\square \longrightarrow$ N times $\square$ Overall evaluation $(0$ to 10$)$ :

ACTIVITIES/JOURNEY

12. Days of beach. How many times have you been in the beach?

13. Hire of vehicle. Have you hire a vehicle to get around the island? Car [ ] Moto [ ] Own car [ ]

$\mathrm{N}$ days until now $\quad \square$ Km already done:

$\mathrm{N}$ total of days:

14. Other means of transport used. Did you use other means of transport? [ ] Yes [ ] No

\begin{tabular}{|c|c|c|c|c|}
\hline MT & Bus & Taxi & Bicycle & Others \\
\hline Days & & & & \\
\hline Routes & & & & \\
\hline
\end{tabular}

15. Yesterday journey:

\begin{tabular}{|c|c|c|c|c|c|c|c|c|}
\hline \multirow[b]{2}{*}{ 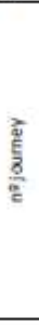 } & \multirow[b]{2}{*}{$\begin{array}{l}\text { Indicate direction or reference that } \\
\text { allows finding the origin and } \\
\text { destination of every journey done }\end{array}$} & TOWN & \multicolumn{2}{|c|}{ REASON } & TIMETABLE & DURATION & TRANSPORT & FAEQUENCY \\
\hline & & $\begin{array}{l}\text { 1. Alaior } \\
\text { 2. Es Migjorn } \\
\text { Gran } \\
\text { 3. Ferreries } \\
\text { 4. Ciutadella } \\
\text { 5. Es Mercadal } \\
\text { 6. Mas } \\
\text { 7. Es Castell } \\
\text { 8. Sant Luis }\end{array}$ & \multicolumn{2}{|c|}{$\begin{array}{l}1 \text { Accommodation } \\
2 \text { Beach } \\
3 \text { Shopping } \\
4 \text { Visit Naturat } \\
\text { Park } \\
5 \text { Visit other } \\
\text { touristic places } \\
6 \text { Restaurant/Bar } \\
7 \text { Doctor } \\
8 \text { Leisure, sport } \\
9 \text { Airport } \\
0 \text { Others }\end{array}$} & $\begin{array}{l}\text { 1. Morning (until } \\
\text { 12h) } \\
\text { 2. Afternoon } \\
\text { (from } 12 \mathrm{~h} \text { to } 17 \\
\text { h) } \\
\text { 3. Evening (from } \\
\text { 17 h to } 20 \mathrm{~h} \text { ) } \\
\text { 4. Night (from } \\
20 \mathrm{~h} \text { to } 24 \mathrm{~h} \text { ) }\end{array}$ & $\begin{array}{l}\text { Journey } \\
\text { duration } \\
\text { (minutes) }\end{array}$ & $\begin{array}{l}1 \text { By foot } \\
2 \text { Car } \\
3 \text { Motorcycle } \\
4 \text { Bicyde } \\
5 \text { Bus } \\
6 \text { Taxo } \\
7 \text { Others (specify) }\end{array}$ & $\begin{array}{l}\text { Number of times } \\
\text { that you have } \\
\text { done this journey } \\
\text { during the stay. }\end{array}$ \\
\hline \multirow{2}{*}{1} & Origin: & & \multirow[t]{2}{*}{ From: } & \multirow[t]{2}{*}{ To: } & & & Principal: & \\
\hline & Destination: & & & & & & Secondary: & \\
\hline \multirow{2}{*}{2} & Origin: & & \multirow[t]{2}{*}{ From: } & \multirow[t]{2}{*}{ To: } & & & Principal: & \\
\hline & \begin{tabular}{|l} 
Destination: \\
\end{tabular} & & & & & & Secondary: & \\
\hline \multirow{2}{*}{3} & Origin: & & \multirow[t]{2}{*}{ From: } & \multirow[t]{2}{*}{ To: } & & & Principal: & \\
\hline & Destination: & & & & & & Secondary: & \\
\hline \multirow{2}{*}{4} & Origin: & & \multirow[t]{2}{*}{ From: } & \multirow[t]{2}{*}{ To: } & & & Principal: & \\
\hline & Destination: & & & & & & Secondary: & \\
\hline \multirow{2}{*}{5} & Origin: & & \multirow[t]{2}{*}{ From: } & \multirow[t]{2}{*}{ To: } & & & Principal: & \\
\hline & Destination: & & & & & & Secondary: & \\
\hline \multirow{2}{*}{6} & Origin: & & \multirow[t]{2}{*}{ From: } & \multirow[t]{2}{*}{ To: } & & & Prindipal: & \\
\hline & Destination: & & & & & & Secondary: & \\
\hline \multirow{2}{*}{7} & Origin: & & \multirow[t]{2}{*}{ From: } & \multirow[t]{2}{*}{ To: } & & & Prindipel: & \\
\hline & Destination: & & & & & & Secondary: & \\
\hline \multirow{2}{*}{8} & Origin: & & \multirow[t]{2}{*}{ From: } & \multirow[t]{2}{*}{ To: } & & & Prindipal: & \\
\hline & Destination: & & & & & & Secondary: & \\
\hline \multirow{2}{*}{9} & Origin: & & \multirow[t]{2}{*}{ From: } & \multirow[t]{2}{*}{ To: } & & & Principst: & \\
\hline & Destination: & & & & & & Secondary: & \\
\hline \multirow{2}{*}{10} & Origin: & & From: & To: & & & Principal: & \\
\hline & Destination: & & & & & & Secondary: & \\
\hline 11 & \begin{tabular}{|l} 
Origin: \\
\end{tabular} & & From: & To: & & & Prindipal: & \\
\hline 11 & Destination: & & & & & & Secondary: & \\
\hline 12 & Origin: & & From: & To: & & & Prindipal: & \\
\hline & Destination: & & & & & & Secondary: & \\
\hline
\end{tabular}

PERSONAL INFORMATION

Sex: Educational level:

Net monthly income:

1 No direct monthly income

2 Compulsory school

2 Less than $600 \mathrm{C} /$ month

3 Between 600 and $1.200 \mathrm{C} /$ month

4 Between 1.200 and $1.600 \mathrm{C} /$ mant

6 Between 2.000 and $3.000 \mathrm{C} /$ mont

3 Secondary school

4 Between 1.200 and $1.600 \mathrm{C} /$ manth

7 Between 3.000 and $4.000 \mathrm{C} / \mathrm{mon}$

8 Between 4.000 and $5.000 \mathrm{f} /$ mont

9 More than $5.000 \mathrm{E} / \mathrm{month}$

Comments: 


\title{
I. ENVIRONMENTAL MANAGEMENT
}

a) Has your facility implemented an environmental management system (ISO 14001, EMAS, etc.)?

Yes Which one? Year:

b) Does your facility use treated water for irrigation or non-drinking water purposes?

No Yes Has the facility a treatment plant?

No

\author{
Yes
}

c) Could you indicate the monthly electric energy consumption of the facility for the year 2010 ?

Has your facility any renewable energy source (photovoltaic panels, thermal energy, etc.)? No Yes

d) Do they selective waste collection? No No 1 Yes

Packaging and plastics
Glass
Paper

\begin{tabular}{l}
0 \\
0 \\
\hline
\end{tabular}
Organic matter Oils Remaining fraction $\mathrm{Kg}$ per day:

\section{OCCUPATION}

a) Could you indicate the monthly overnight stays for 2010 ? (If not, indicate monthly occupation rates)

b) Which months does the lodging facility open?

c) Does your facility offer an all-inclusive package? Which fraction of customers uses this service?

d) Which touristic activities in Menorca do you offer?

Thank you very much for your time and help. The memory of the first edition of the study is available on the website www.obsam.cat 